\title{
Decision Support System for Determining The Type of Workout Using the Fuzzy Analythical Hierarchy Process (F-AHP) Method In STIKI GYM
}

Sistem Pendukung Keputusan Penentuan Jenis Workout Menggunakan Metode Fuzzy Analythical Hierarchy Process (F-AHP) Pada STIKI GYM

\section{Nyoman Tri Anindia Putra ${ }^{1}$, Ni Komang Ayu Sinariyani², Nia Maharani ${ }^{3}$, Ketut Sepdayana Kartini ${ }^{4}$}

\section{1,2,3,4 Teknik Informatika, STMIK STIKOM, Indonesia}

${ }^{1}$ trianindiaputra@stiki-indonesia.ac.id, 2nkmayusinariyani04@gmail.com,

${ }^{3}$ maharani.nst@gmail.com, ${ }^{4}$ sepdyana27@gmail.com

\section{Informasi Artikel}

Received: 27 January 2021

Revised: 8 February 2021

Accepted: 23 February 2021

Published: 28 February 2021

Keywords: Workout; F-AHP;

Decision Support System

Kata kunci: Workout; F-AHP;

Sistem Pendukung Keputusan

\begin{abstract}
Purpose: Decision Support System for Determining the Type of Workout Using the Fuzzy Analythical Hierarchy Process (F-AHP) Method The STIKI GYM was created to make it easier for trainers to provide training for STIKI GYM participants who carry out workouts at STIKI GYM. Meanwhile, for STIKI GYM participants, the system can make it easier to carry out workout activities according to their respective body loads.

Design/methodology/approach: Fuzzy Analythical Hierarchy Process (F-AHP) Method and being tested with black box testing

Findings/result: Users can find out workout activities by entering the criteria for body weight, height, and exercise intensity into the system and helping trainers provide training in accordance with the recommendations for workout activities from the Decision Support System for Determining the Types of Workout Using the Fuzzy Analythical Hierarchy Process (F-AHP) Method at STIKI GYM.

Originality/value/state of the art: The Decision Support System for determining the Type of Workout is indeed implemented at STIKI GYM by using data support in the form of interview results and participant data from STIKI GYM.

Abstrak

Tujuan: Sistem Pendukung Keputusan Penentuan Jenis Workout Menggunakan Metode Fuzzy Analythical Hierarchy Process (F-AHP) Pada STIKI GYM di buat untuk mempermudah trainer dalam memberikan pelatihan bagi peserta STIKI GYM yang melaksanakan workout pada STIKI GYM. Sedangkan untuk peserta STIKI GYM, dengan adanya sistem dapat mempermudah dalam melakukan kegiatan workout sesuai dengan beban tubuh masing - masing.
\end{abstract}




\section{Perancangan/metode/pendekatan: Metode Fuzzy}

Analythical Hierarchy Process (F-AHP) dengan pengujian

black box testing

Hasil: User dapat mengetahui kegiatan workout dengan memasukkan kriteria berat badan, tinggi badan, serta intensitas latihan ke dalam sistem dan membantu trainer memberikan pelatihan sesuai dengan rekomendasi kegiatan workout dari Sistem Pendukung Keputusan Penentuan Jenis Workout Menggunakan Metode Fuzzy Analythical Hierarchy Process (F-AHP) Pada STIKI GYM.

Keaslian/ state of the art: Sistem Pendukung Keputusan penentuan Jenis Workout memang benar diimplementasikan pada STIKI GYM dengan menggunakan dukungan data berupa hasil wawancara dan data peserta dari STIKI GYM.

\section{Pendahuluan}

Berbagai macam kegiatan dapat dilakukan dalam mengisi waktu luang seperti halnya mengisi waktu luang dengan olahraga atau latihan fisik. Kegiatan olahraga harus dilakukan dengan baik dan benar sehingga terhindar dari cidera fisik yang tidak diinginkan. Seperti dalam melaksanakan tiap sesi latihan (workout) atau an exercise session untuk mengisi waktu luang ataupun sebagai hobi yang dijalankan. Salah satu kampus yang menerapkan olahraga sebagai kebiasaan pola hidup sehat yaitu kampus STMIK STIKOM INDONESIA (STIKI). Kampus STIKI Indonesia merupakan kampus IT yang mempunyai fasilitas GYM didalamnya serta peralatan GYM yang sudah memadai dalam melaksanakan kegiatan sesi latihan (workout) untuk seorang pemula dalam melaksanakan kegiatan olahraga.

Dalam pelaksanaaan olahraga pada STIKI GYM akan diarahkan oleh trainer meliputi tahap pengenalan alat, cara penggunaan alat-alat yang tersedia, serta dasar-dasar pemanasan sebelum melakukan kegiatan olahraga. Setelah itu trainer hanya memberikan program latihan umum dengan membuat jadwal program latihan pada Microsoft excel dan trainer tidak melaksanakan pemberian latihan lagi sekiranya pemula telah paham cara menggunakan alat. Dalam pemberian latihan pada tahap sesi latihan (workout) trainer memberikan pelatihan dengan melihat dari fisik serta pengelaman dalam berolahraga dari masing-masing pemula dalam melaksanakan olahraga dimana kriteria kualitas utama yang dilihat yaitu tinggi badan, berat badan, serta intensitas latihan tanpa mendapat hasil kuantitas secara pasti dengan menggunakan perhitungan. Ketidak tepatan dalam memberikan penilaian terhadap sesi latihan yang diambi berdampak pada hasil keputusan akhir yang diberikan akan kurang tepat, yang menimbulkan salahnya pengambilan setiap sesi latihan (workout). Melihat sistem pemberian sesi latihan (workout) yang berjalan saat ini, dimana belum adanya data pendukung yang terkomputerisasi menjadikan pemberian latihan masih diragukan dalam efektifitas untuk mencapai tujuan dari pemula yang melaksanakan olahraga pada STIKI GYM.

Untuk mendukung pemilihan jenis sesi (workout) bagi pemula, maka perlu adanya sebuah sistem yang dapat menentukan jenis sesi latihan yang sesuai dengan syarat dan kriteria yang telah ditentukan. Sistem ini juga diharapkan dapat menjadi sebuah alat bantu dalam pengambilan keputusan yang dilakukan oleh para pengambil keputusan dalam memperluas pertimbangan yang ada. Sistem pendukung keputusan yang akan digunakan membutuhkan 
sebuah metode pendukung dalam penyelesaian permasalahan. Metode yang digunakan dalam penelitian ini yaitu metode Fuzzy Analytical Hierarchy Process (F-AHP). Dimana metode ini dapat mendeskripsikan keputusan yang masih samar-samar, kurang tepat atau dalam bentuk linguistic dan pola yang tidak jelas sehingga didapatkan sebuah gambaran yang lebih baik ke dalam bentuk data kuantitatif, dapat diselsaikan dengan menggunakan metode Fuzzy Analythical Hierarchy Process (F-AHP). Penerapan sistem pendukung keputusan yang membuktikan bahwa metode (F-AHP) dapat digunakan dalam menangani kriteria kualitatif dan kuantitatif, pada riset penelitian terdahulu [1] Sistem Pendukung Keputusan (SPK) Pemilihan Karyawan Terbaik Menggunakan Metode Fuzzy Ahp (F-Ahp) mampu menghasilkan perankingan yang sesuai dengan perhitungan manual serta pembobotan yang lebih cepat dilakukan sehingga didapatkan nilai dengan akurasi yang tinggi.

Metode Fuzzy Analythical Hierarchy Process (F-AHP) dapat mendukung sistem keputusan pemilihan jenis sesi latihan (workout) dengan menggunkan kriteria dan sub kriteria [2] dengan output dari sistem yaitu dapat memberikan informasi mengenai rekomendasi sesi latihan (workout) yang sesuai dengan beban tubuh dari pemula yang melaksanakan olahraga pada STIKI GYM. Sehingga didapatkan hasil yang tepat dengan dukungan metode yang sesuai dalam penentuan rekomendasi pemilihan jenis (workout) untuk seorang pemula sesuai dengan kriteria yang telah ditentukan. Berdasarkan pemaparan latar belakang yang disampaikan, maka penulis melakukan penelitian dengan judul "Sistem Pendukung Keputusan Penentuan Jenis Workout Menggunakan Metode Fuzzy Analythical Hierarcy Process (F-AHP) Pada STIKI GYM”.

\section{Metode/Perancangan}

Pengumpulan data dilakukan berdasarkan observasi dan wawancara terhadap data yang memang sudah ada [3]. Tahapan penelitian yang dilakukan dengan hasil dari metode pengumpulan data baik melalui data primer dan data skunder [4]. Pengumpulan didasarkan dengan keperluan data yang berkaitan dengan sistem yang dibuat dengan informasi berbasis komputer yang dapat meminimalisir terjadinya kesalahan [5]. Penggunaan Bahasa pemrograman PHP dan HTML dalam penerapan design yang ditampilkan senyaman mungkin dalam kemudahan user berinteraksi dengan sistem.

\subsection{Sistem Flow Diagram}

Sebelum itu, pemodelan sistem dijelaskan dengan dasar data - data yang didapatkan oleh peneliti sehingga menghasilkan alur sistem yang diusulkan sebagai berikut. Berikut merupakan Gambar 1. Sistem Flow Diagram Penentuan Jenis Workout pada gambaran analisis sistem data yang diimplementasikan menggunakan sistem flow diagram dalam penentuan jenis workout pada STIKI GYM. 


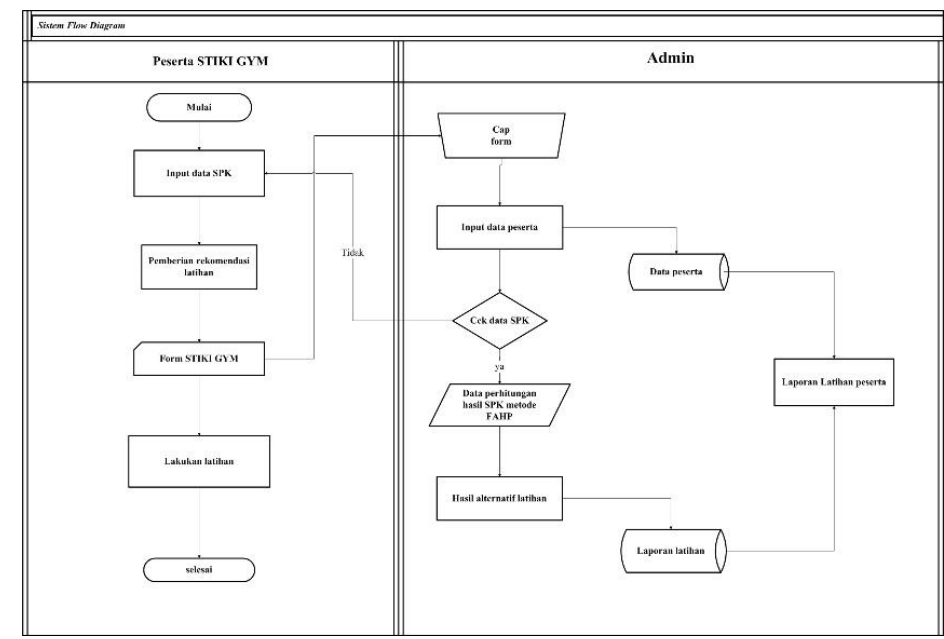

Gambar 1. Sistem Flow Diagram Penentuan Jenis Workout

\subsection{Waterfall Model}

Dalam pengembangan sistem metode yang digunakan yaitu metode waterfall. Menurut [6] Model waterfall atau air terjun menunjukkan pendekatan, sistematis skuensial untuk pengembangan perangkat lunak yang dimulai dengan spesifikasi pelanggan persyaratan dan berlangsung melalui perencanaan konstruksi pemodelan dan penyebaran yang berpuncak pada dukungan terus-menerus dari perangkat lunak. Gambar 2. Metode Waterfall merupakan metode yang digunakan adalam pengembangan sistem pendukung keputusan penetuan jenis workout pada STIKI GYM.

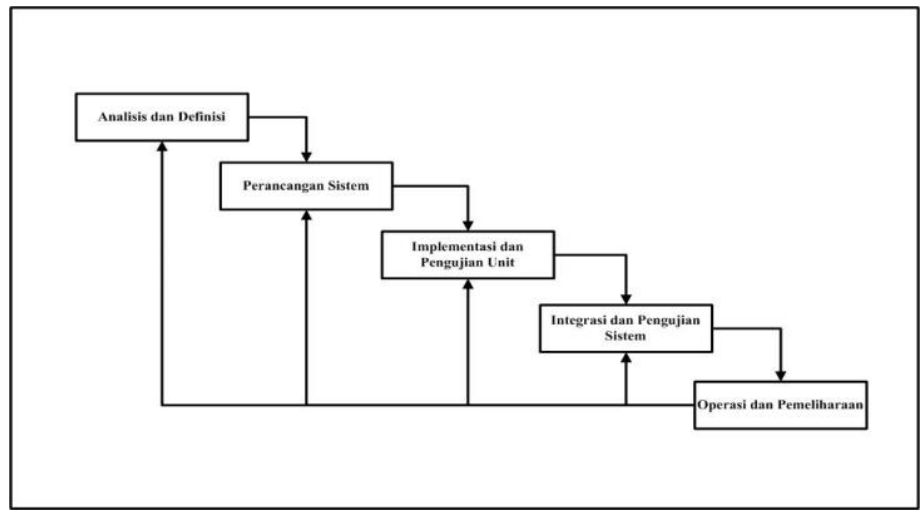

Gambar 2. Metode Waterfall

\subsection{Sistem Pendukung Keputusan Metode F-AHP}

Menurut [7] Sistem Pendukung Keputusan (SPK) atau Decision Support System (DSS) adalah sistem informasi interaktif yang menyediakan informasi, pemodelan, dan pemanipulasian data yang digunakan untuk membantu pengambilan keputusan pada situasi yang semi terstruktur dan situasi yang tidak terstruktur dimana tidak seorangpun tahu secara pasti bagaimana keputusan seharusnya dibuat. Logika fuzzy diperkenalkan oleh Prof. Lotfi Astor Zadeh pada tahun 1962, logika fuzzy merupakan metode sistem control pemecahan masalah yang cocok diimplementasikan pada sistem, yang sederhana, kecil, embedded system dan system control lainnya, fuzzy memungkinkan nilai keanggotaan berada diantara 0 atau 1, namun besar nilainya tergantung pada bobot keanggotaan yang dimilikinya.berbeda dengan AHP merupakan 
representasi dari permasalahan yang kompleks dalam suatu struktur multilevel yang diikuti level faktor, krteria, sub kriteria dan seterusnya hingga level terakhir alternatif [8]. Metode perhitungan data menggunakan perhitungan Fuzzy Analythical Hierarchy Process (F-AHP) menurut [9] F-AHP merupakan gabungan metode AHP dengan pendekatan konsep fuzzy dimana dapat menutupi kelemahan yang terdapat pada pemodelan metode AHP dimana permasalahan terhadap kriteria yang memiliki sifat subjektif lebih banyak dengan ketidakpastian bilangan dipresentasikan dengan urutan skala.

Menurut [10] langkah - langkah penyelesaian metode F-AHP sebagai berikut :

1. Membuat struktur hirarki permasalahan dan menentukan nilai pada matriks perbandingan berpasangan antar kriteria dengan skala TFN.

2. Menghitung nilai sintesis fuzzy $(\mathrm{Si})$ pioritas dengan rumus :

Dimana $: \mathrm{Si}=\sum_{j=1}^{m} M_{i}^{j} \mathrm{x}=\frac{1}{\sum_{j=1}^{n} \sum_{j=1}^{m} M_{i}^{j}}$

3. Menghitung nilai vector (V) dan nilai ordinat defuzzyfikasi (d'). jika hasil yang diperoleh pada setiap matrik fuzzy, M2 $\geq \mathrm{M} 1 \mathrm{M} 2=(12, \mathrm{~m} 2, \mathrm{u} 2) \mathrm{M} 1=(11, \mathrm{~m} 1, \mathrm{u} 1)$. Maka nilai vector dirumuskan : $\mathrm{V}\left(\mathrm{M}_{2} \geq \mathrm{M}_{1}=\sup [\min (\mu \mathrm{M} 1(\mathrm{x}), \min (\mu \mathrm{M} 2(\mathrm{y})))]\right.$

Jika hasil nilai fuzzy lebih besar dari $k, M_{i}(i=1,2, . . k)$

Maka nilai vector dapat didefinisikan sebagai berikut :

$\mathrm{V}(\mathrm{M} \geq \mathrm{M} 1, \mathrm{M} 2, \ldots \mathrm{Mk})=\mathrm{V}(\mathrm{M} \geq \mathrm{M} 1)$ dan $\mathrm{V}(\mathrm{M} \geq \mathrm{Mk})=\min \mathrm{V}(\mathrm{M} \geq \mathrm{Mi})$

Asumsikan bahwa, d' (Ai) $=\min V(\mathrm{Si} \geq \mathrm{Sk})$

Untuk $k=1,2, \ldots . ., n ; k \neq i$, maka nilai bobot vector

$W^{\prime}=\left(d^{\prime}(A 1), d^{\prime}(A 2), \ldots \ldots, d^{\prime}(A n)\right)$

Dimana $A i=1,2, \ldots ., n$ adalah $n$ elemen keputusan.

4. Melakukan normalisasi bobot vector fuzzy $(\mathrm{W})$.

Setelah dilakukan normalisasi maka nilai bobot vector yang ternormalisasi adalah seperti rumus berikut :

$\mathrm{W}=(\mathrm{d}(\mathrm{A} 1), \mathrm{d}(\mathrm{A} 2) \ldots \mathrm{d}(\mathrm{An}))$

Dimana $\mathrm{W}$ adalah bilangan non fuzzy.

\subsection{Pengumpulan Data}

Tahapan penelitian yang dilakukan sesuai dengan kebutuhan data yang ada dengan melakukan (1) observasi ke tempat yang dilakukan penelitian yaitu STIKI GYM, (2) wawancara yang dilakukan langsung oleh penulis dengan trainer STIKI GYM yaitu I Gede Oka Suyasa. (3) studi pustaka yang dilakukan dengan mengumpulkan berbagai data pendukung melalui sumber referensi berupa jurnal ataupun buku untuk penunjang penelitian sistem yang dibangun. (4) dokumentasi dilakukan oleh penulis dengan mencari dokumen yang didapatkan langsung dari pihak STIKI GYM.

\subsection{Pengujian Sistem (Black Box Testing)}

Pengujian penelitian menggunakan pengujian blackbox testing dimana menurut [11]blackbox testing merupakan salah satu metode yang mudah digunakan karena hanya memerlukan batas 
bawah dan atas dari data yang diharapkan. Estimasi banyaknya data uji dihitung melalui banyak field data entri yang akan diuji, aturan entri yang dipenuhi serta kasus batas atas dan bawah yang memenuhi diketahui jika fungsionalitas masih dapat menerima masukan data yang tidak diharapkan maka menyebabkan data yang disimpan kurang valid [12].

\subsection{Gambaran Umum Sistem}

Berdasarkan system flow diagram penentuan jenis (workout) pada gambar 1 , dimana sistem nantinya sebagai data yang mengatur dari masukan (input) dan keluaran (output) [13]. Sistem yang dibuat terdapat dua akses yang nantinya berinteraksi dengan sistem yaitu admin (Pembina STIKI GYM, Sekterasis, dan Trainer) dimana admin dapat masuk dan dapat melakukan pengolahan data dalam sistem pendukung keputusan penentuan jenis workout. Data tersebut meliputi data peserta, data SPK, data workout, data user, serta laporan. Untuk user (peserta STIKI GYM) dapat masuk ke sistem untuk input data SPK yang nantinya dikemas dalam satu sistem pendukung keputusan penentuan jenis workout pada STIKI GYM dan natinya akan disimpan dalam database. Pada penulisan metode terdapat tabel, gambar, maupun persamaan yang digunakan dalam penelitian tersebut. Pada penjelasan sistem melalui gambar sistem dipaparkan pada Gambar 3. Gambaran umum sistem.

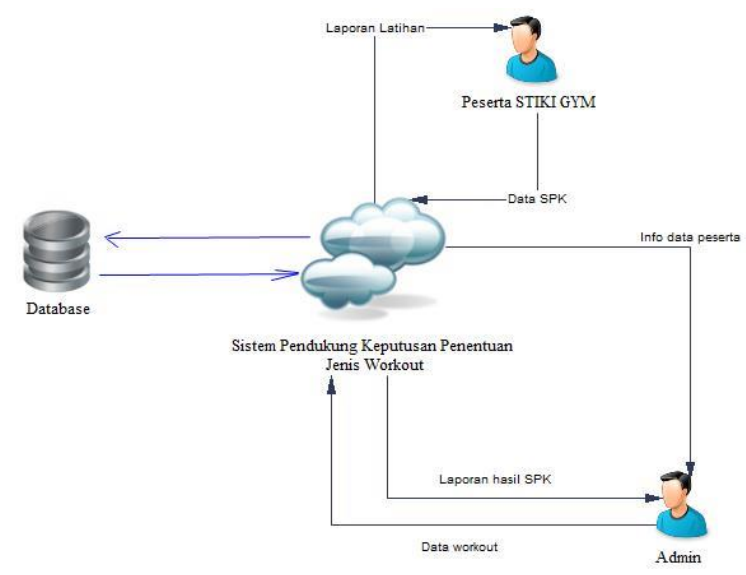

Gambar 3. Gambaran Umum Sistem

\subsection{Diagram Konteks}

Berikut merupakan Gambar 4. Diagram konteks yang menggambarkan seluruh sistem, dimana terdapat dua entitas untuk dapat mengelola data yang ada pada sistem. Peserta sebagai user yang melaksanakan input data SPK dan kegiatan workout, admin sebagai pengelola data laporan, data peserta, dan input data workout, mengelola hasil perhitungan SPK.

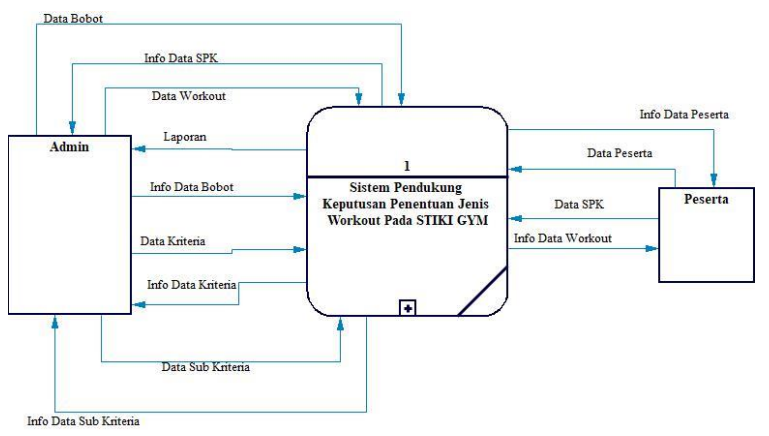

Gambar 4. Diagram Konteks 


\section{Hasil dan Pembahasan}

Berikut merupakan hasil dan pembahasan dari sistem pendukung keputusan penentuan jenis workout pada STIKI GYM menggunakan metode Fuzzy Analythical Hierarchi Process (FAHP). Sehingga didapatkan hasil yang akurat dalam setiap perhitungan yang dilakukan [14]. Dalam hasil wawancara didapatkan kriteria, sub kriteria serta alternatif yang digunakan untuk sistem pendukung keputusan penentuan jenis workout pada Gambar 5. Hirarki proses dimana dalam hirarki terdapat tiga kriteria utama yaitu berat badan, tinggi badan dan intensitas latihan. Dalam masing - masing kriteria mempunyai sub kriteria dan tiga alternatif yaitu kebugaran, pembentukan massa otot serta pola diet. Berikut gambaran hirarki proses penentuan jenis workout pada STIKI GYM.

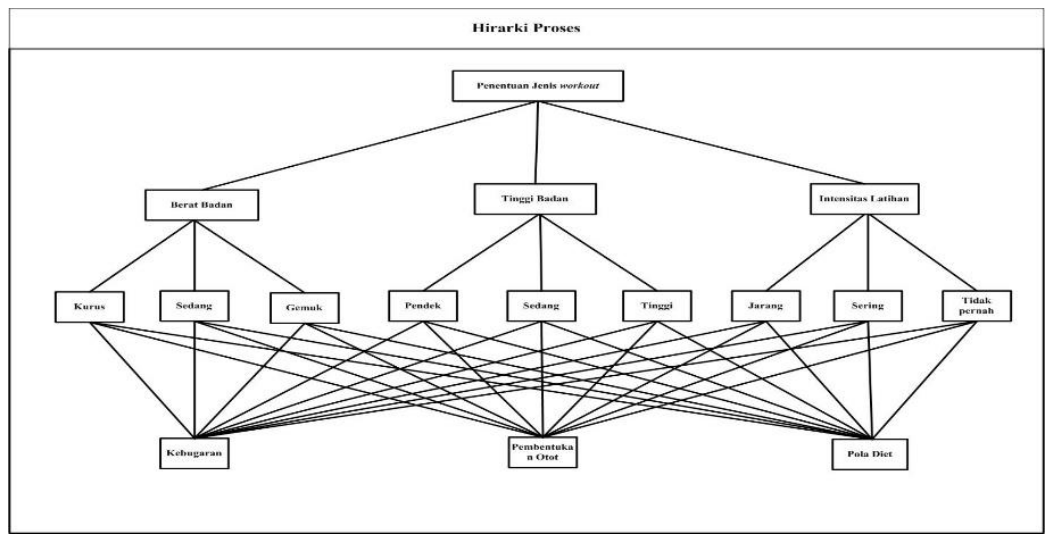

Gambar 5. Hirarki Proses

Dalam hirarki proses terdapat keterangan dari masing -masing kriteria, sub kriteria, dan alternatif yang dipaparkan pada Tabel 1. Keterangan hirarki proses.

Tabel 1. Keterangan Hirarki Proses

Kriteria

Berat Badan (K1)

Tinggi Badan (K2)

Intensitas Latihan (K3)
Sub Kriteria

Berat (K1Sk1)

Sedang (K1Sk2)

Kurus (K1Sk3)

Tinggi (K2Sk1)

Sedang (K2Sk2)

Pendek (K2Sk3)

Sering (K3Sk1)

Jarang (K3Sk2)

Tidak Pernah (K3Sk3)

\section{Alternatif}

Kebugaran (A1)

Pembentukan Otot (A2)

Pola Diet (A3) 


\section{Perhitungan Metode Fuzzy Analythical Hierarchi Process (F-AHP)}

\section{Pembobotan Kriteria}

Pembobotan kriteria telah ditetapkan oleh pengambil keputusan dalam hal ini yaitu pengelola bidang sarana dan prasarana STIKI GYM yang terdapat tiga kriteria utama dalam penentuan jenis workout. Pembobotan dapat dilihat dalam Tabel 2. Pembobotan kriteria.

Tabel 2. Pembobotan Kriteria

\begin{tabular}{llll} 
& K1 & K2 & K3 \\
\hline K1 & 1 & 3 & 2 \\
\hline K2 & 0,333 & 1 & 2 \\
\hline K3 & 0,5 & 0,5 & 1 \\
\hline Total & 1,833 & 4,5 & 5 \\
\hline
\end{tabular}

2. Perbandingan Matriks Berpasangan Kriteria (F-AHP)

Matriks berpasangan kriteria F-AHP dan perhitungan jumlah baris pada setiap kolom. Pada tabel ini dari Tabel 3. Matriks berpasangan kriteria (F-AHP) akan diubah ke dalam bentuk matriks perbandingan berpasangan kriteria F-AHP dan perhitungan jumlah baris setiap kolom.

Tabel 3. Matriks Berpasangan Kriteria (F-AHP)

\begin{tabular}{|c|c|c|c|c|c|c|c|c|c|c|c|c|}
\hline & \multicolumn{3}{|c|}{ K1 } & \multicolumn{3}{|c|}{ K2 } & \multicolumn{3}{|c|}{ K3 } & \multicolumn{3}{|c|}{ Jumlah baris } \\
\hline & 1 & $\mathrm{M}$ & $\mathrm{u}$ & 1 & $\mathrm{~m}$ & $\mathrm{U}$ & $\mathrm{L}$ & $\mathrm{m}$ & $\mathrm{u}$ & 1 & $\mathrm{~m}$ & $\mathrm{u}$ \\
\hline K1 & 1 & 1 & 1 & $\begin{array}{ll}1 / \\
2\end{array}$ & $\begin{array}{c}2 / \\
3\end{array}$ & 1 & $\begin{array}{l}1 / \\
2\end{array}$ & 1 & $\begin{array}{l}3 / \\
2\end{array}$ & 2 & 2,6666666667 & 3,5 \\
\hline K2 & $\begin{array}{l}1 / \\
2\end{array}$ & $\begin{array}{c}2 / \\
3\end{array}$ & 1 & 1 & 1 & 1 & $\begin{array}{l}1 / \\
2\end{array}$ & 1 & $\begin{array}{l}3 / \\
2\end{array}$ & 2 & 2,6666666667 & 3,5 \\
\hline K3 & $\begin{array}{c}2 / \\
3\end{array}$ & 1 & 2 & $\begin{array}{l}21 \\
3\end{array}$ & 1 & 2 & 1 & 1 & 1 & 2,3333333333 & 3 & 5 \\
\hline & & & & & & & & & & 6,3333333333 & 8,3333333334 & 12 \\
\hline
\end{tabular}

3. Menentukan Nilai Sintesis Fuzzy (Si) Prioritas

Nilai sisntesis fuzzy diperoleh dari perhitungan nilai baris pada kolom yang telah ditentukan sehingga perhitungan sisntesis fuzzy dari masing - masing (SKi) dapat dilihat sebagai berikut :

$$
\begin{aligned}
\text { SK1 } & =(2,2,6666666667,3.5) \times\left(\frac{1}{12}, \frac{1}{8,3333333334}, \frac{1}{6,3333333333}\right) \\
& =(2,2,6666666667,3.5) \times(0.0833333333,0.12,0.1578947369) \\
& =(0.1666666666,0.32,0.5526315792) \\
\text { SK2 } & =(2,2,6666666667,3.5) \times\left(\frac{1}{12}, \frac{1}{8,3333333334}, \frac{1}{6,3333333333}\right) \\
& =(2,2,6666666667,3.5) \times(0.0833333333,0.12,0.1578947369) \\
& =(0.1666666666,0.32,0.5526315792) \\
\text { SK3 } & =(2,3333333333,3,5) \times\left(\frac{1}{12}, \frac{1}{8,33333333334}, \frac{1}{6,3333333333}\right) \\
& =(2,3333333333,3,5) \times(0.0833333333,0.12,0.1578947369)
\end{aligned}
$$




$$
=(0.1944444443,0.36,0.789473698)
$$

Sehingga dihasilkan tabel perhitungan nilai sintesis fuzzy (si) kriteria didapatkan melalui hasil perhitungan nilai 1,m,u pada Tabel 3. dari perhitungan fuzzyfikasi [15] sehingga didapatkan hasil perhitugan pada Tabel 4. Perhitungan Nilai Sintesis Fuzzy (si) Kriteria.

Tabel 4. Perhitungan Nilai Sintesis Fuzzy (si) Kriteria

\begin{tabular}{llll} 
& & SI & \\
\hline VSK 1 & l & m & u \\
\hline VSK 2 & 0.1666666666 & 0.32 & 0.5526315792 \\
\hline VSK 3 & 0.1666666666 & 0.32 & 0.5526315792 \\
\hline
\end{tabular}

4. Menentukan Nilai Vector (V) dan Nilai Ordinat Defuzzyfikasi (d')

a. Kriteria 1 (K1), nilai vectornya adalah VSK1 $\geq(\mathrm{VSK} 2$, VSK3)

VSK $1 \geq \operatorname{VSK} 2=1.0686333518$

$\operatorname{VSK} 1 \geq \operatorname{VSK} 3=1$

d' $($ VSK 1$)=\min (1.0686333518,1)$

sehingga diperoleh nilai ordinat d' $\mathbf{1 . 0 6 8 6 3 3 3 5 1 8}$

b. Kriteria 2 (K2), nilai vectornya adalah VSK $2 \geq$ ( VSK1, VSK3)

VSK $2 \geq \operatorname{VSK} 1=0.6145895907$

$\operatorname{VSK} 2 \geq \operatorname{VSK} 3=1$

d' $($ VSK 2$)=\min (0.6145895907)$

sehingga diperoleh nolai ordinat d' $\mathbf{0 . 6 1 4 5 8 9 5 9 0 7}$

c. Kriteria 3 (K3), nilai vectornya adalah VSK $3 \geq(\mathrm{VSK} 1$, VSK 2)

$\operatorname{VSK} 3 \geq \operatorname{VSK} 1=1$

VSK $3 \geq \operatorname{VSK} 2=1$

Sehingga diperoleh nilai ordinat d' 1

Berdasarkan nilai ordinat $\mathrm{K} 1, \mathrm{~K} 2$, dan $\mathrm{K} 3$ maka nilai bobot vector yang ditentukan sebagai berikut : $\mathrm{W}^{\prime}=(1.0686333518,0.6145895907,1)$

5. Normalisasi Bobot Vector Fuzzy (W):

Untuk mengetahui bobot dari vector yang sudah dinormalisasi dengan perhitungan tiap elemen dibagi jumlah bobot vector itu sendiri sehingga didapatkan penjumlahan normalisasi bernilai satu. Sehingga setiap vector akan sama dengan nilai bobot prioritas global seperti pada Tabel 5. Normalisasi bobot vector fuzzy $(\mathrm{W})$.

Tabel 5. Normalisasi Bobot Vector Fuzzy (W)
$\mathbf{W}^{\prime}$
Total $\mathbf{W}^{\prime}$
W' Lokal 


\begin{tabular}{|c|c|c|c|}
\hline K1 & 1.0686333518 & \multirow{3}{*}{2.6832229425} & 0.3982648385 \\
\hline K2 & 0.6145895907 & & 0.2290490219 \\
\hline K3 & 1 & & 0.3726861396 \\
\hline
\end{tabular}

\section{Nilai Alternatif}

Merupakan rentan nilai yang dianjurkan dalam hasil akhir perankingan yang dilaksanakan. Nilai alternatif ini sebagai batasan nilai untuk menentukan hasil dari setiap perhitungan yang diberikan kepada pemula yang melaksanakan olahraga pada STIKI GYM. Terdapat tiga alternatif yaitu kebugaran (A1) rentang nilai $\leq 300$ - 355, massa otot (A2) rentang nilai 350 400 , diet (A3) rentang nilai $\geq 390$ dimana masing-masing dari alterntif terdapat batasan nilai linguistik untuk menentukan alternatif pilihan.

\section{Perankingan Alternatif dan Hasil Perhitungan}

Pada Tabel 6. Tabel hasil perhitungan merupakan tabel yang memuat hasil dari perhitungan setiap kriteria dan sub kriteria dengan bobot lokal masing - masing. Dimana pada setiap kriteria yang ada, user memasukkan inputan berat badan, tinggi badan serta intensitas latihan untuk mengetahui jenis workout yang didapat. Dari inputan yang dilaksanakan oleh user terhubung langsung dengan admin dan akan dikalikan dengan bobot prioritas kriteria. Dari hasil kali didapat bobot sub kriteria dikali dengan inputan sub kriteria = hasil bobot kriteria : hasil bobot sub kriteria, dari masing masing hasil tersebut akan dijumlahkan sehingga di dapatkan nilai perhitungan optimum dengan hasil yang akurat melalui metode perhitungan. Terlihat pada Tabel 7. Hasil perhitungan bahwa Ida Bagus Gede Widnyana Masthara dengan berat badan 89 $\mathrm{kg}$, tinggi badan $170 \mathrm{~cm}$, dan intensitas latihan 2, didapatkan hasil perhitungan dengan nilai total 430. 2454251911415 mendapatkan ranking pertama dengan alternatif yang di dapat dari hasil perhitungan yaitu pola diet. Berikut merupakan gambar tabel hasil perhitungan dengan beberapa peserta yang melaksanakan olahraga pada STIKI GYM.

Tabel 6. Tabel Hasil Perhitungan

\begin{tabular}{|c|c|c|c|c|c|c|c|}
\hline & Kriteria & & K1 & & & $\mathbf{K} 2$ & \\
\hline & Bobot Kriteria & & 0,398 & & & 0,229 & \\
\hline & Sub Kriteria & K1Sk1 & K1Sk2 & K1Sk3 & K2Sk1 & K2Sk2 & K2Sk3 \\
\hline & Bobot Sub Kriteria & 0,332 & 0,365 & 0,302 & 0,376 & 0,333 & 0,291 \\
\hline No & Alternatif & & & & & & \\
\hline 1 & Pola Diet & 35.56425702811245 & 48.523287671232886 & 117.29139072847684 & 34.51241134751773 & 58.45345345345345 & 133.78006872852234 \\
\hline 2 & Kebugaran & 15.98393574297189 & 21.808219178082194 & 52.71523178807948 & 31.467198581560286 & 53.2957957957958 & 121.97594501718216 \\
\hline 3 & Massa Otot & 23.975903614457835 & 32.71232876712329 & 79.07284768211922 & 32.4822695035461 & 55.01501501501501 & 125.9106529209622 \\
\hline 4 & Pola Diet & 29.96987951807229 & 40.89041095890411 & 98.84105960264901 & 36.33953900709219 & 61.548048048048045 & 140.86254295532646 \\
\hline 5 & $\begin{array}{c}\text { Kebugaran dan massa } \\
\text { otot }\end{array}$ & 21.977911646586346 & 29.986301369863014 & 72.48344370860927 & 33.49734042553192 & 56.734234234234236 & 129.8453608247423 \\
\hline
\end{tabular}


Tabel 7. Tabel Hasil Perhitungan (lanjutan)

\begin{tabular}{|c|c|c|c|c|c|}
\hline \multicolumn{3}{|c|}{$\mathbf{K 3}$} & \multirow{4}{*}{ Total } & \multirow{3}{*}{ Ranking } & \multirow{3}{*}{ Nama } \\
\hline \multicolumn{3}{|c|}{0,373} & & & \\
\hline K3Sk1 & K3Sk2 & K3Sk3 & & & \\
\hline 0,332 & 0,365 & 0,302 & & & \\
\hline 0.748995983935743 & 1.021917808219178 & 2.4701986754966887 & 430.2454251911415 & 1 & $\begin{array}{c}\text { Ida Bagus Gede Widnyana } \\
\text { Masthara } \\
\end{array}$ \\
\hline 0.3744979919678715 & 0.510958904109589 & 1.2350993377483444 & 299.3668823374976 & 5 & Ananda \\
\hline 1.1234939759036144 & 1.5328767123287672 & 3.705298013245033 & 355.5306862047011 & 3 & Luh Made Dwi Lestari \\
\hline 0.748995983935743 & 1.021917808219178 & 2.4701986754966887 & 412.6925925577437 & 2 & I Wayan Ryan Haryanto \\
\hline 1.1234939759036144 & 1.5328767123287672 & 3.705298013245033 & 350.88626091104453 & 4 & $\begin{array}{c}\text { Ni Putu Ayu Evi Wahyu } \\
\text { Pramesty }\end{array}$ \\
\hline
\end{tabular}

\section{Implementasi Sistem}

Implementasi sistem menggunakan bahasa pemrograman PHP dan HTML. Adapun proses operasi yang diimplementasikan ke sistem dalam sistem pendukung keputusan penentuan jenis workout pada STIKI GYM yaitu memberikan tampilan sebagai berikut.

1. Pada Gambar 6. Halaman data SPK merupakan halaman pertama jika user telah berhasil login. Pada halaman ini akan mengarahkan user ke halaman perhitungan data SPK. Dimana setelah user selesai input data dengan benar, maka user akan mendapat alternatif hasil rekomendasi latihan workout.

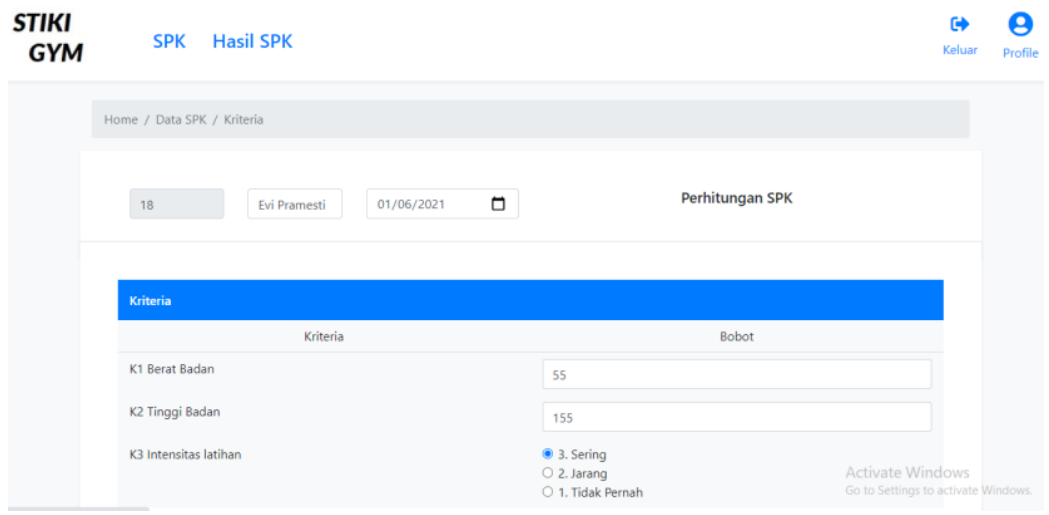

Gambar 6. Halaman Data SPK

2. Halaman hasil SPK akan menampilkan satu halaman yang memuat data hasil rekomendasi alternatif latihan untuk user dari inputan perhitungan dari setiap bobot inputan kriteria dan sub kriteria dimana nantinya akan disimpan ke dalam database SPK dan dilakukan perhitungan oleh sistem sesuai dengan perhitungan manual yang telah dilakukan. Sehingga didapatkan nilai akurat yang sesuai untuk menentukan alternatif yang ada. Berikut pada Gambar 7. Halaman hasil perhitungan SPK. 


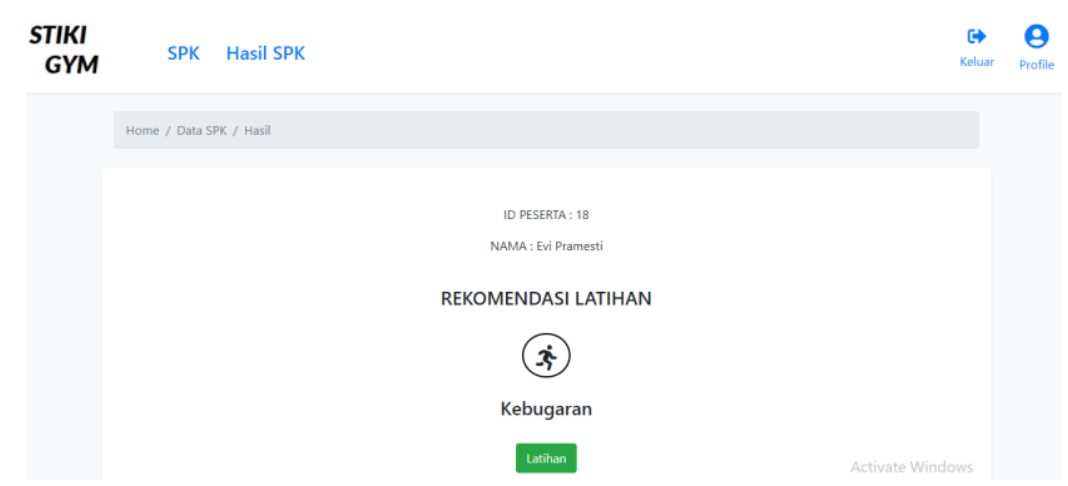

Gambar 7. Halaman Hasil Perhitungan SPK

3. Halaman perhitungan SPK merupakan halaman yang berisi hasil perhitungan kriteria dan sub kriteria yang telah terkomputerisasi dan mendapat hasil yang sesuai metode F-AHP hasil perhitungan ini merupakan hasil dari inputan SPK user yang nantinya terhubung dengan SPK admin dan hasil perhitungan ini akan dikelola oleh admin. Terdapat button kembali untuk kembali ke halaman perhitungan sebelumnya. Berikut Gambar 8. Halaman hasil perhitungan SPK.

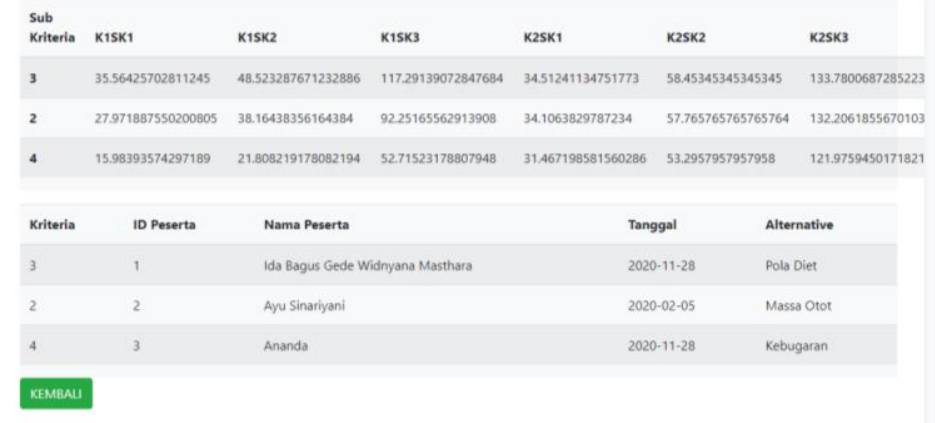

Gambar 8. Halaman Hasil Perhitungan SPK

\section{Pengujian Sistem}

Pengujian sistem merupakan kegiatan untuk memastikan apakah fungsi dan atribut pada sistem telah bekerja dengan baik [16], dalam sistem pendukung keputusan penentuan jenis workout pada STIKI GYM menggunakan pengujian sistem blackbox testing dengan pengujian form dan implementasi sistem telah sesuai harapan. Berikut merupakan Tabel 8. Pengujian menu SPK untuk mengetahui apakah semua menu berfungsi dengan benar dan dapat menampilkan menu yang diharapkan. 
Tabel 8. Pengujian Menu SPK

\begin{tabular}{lllll} 
No & Fungsi & Skenario & Hasil Sistem \\
\hline 1 & Tampilan halaman SPK & Pengguna diarahkan ke tampilan data SPK & Sesuai harapan \\
\hline 2 & $\begin{array}{l}\text { User mengklik input } \\
\text { kriteria }\end{array}$ & $\begin{array}{l}\text { Sistem menampilkan kolom inputan bobot untuk } \\
\text { data kriteria meliputi K1,K2,K3 }\end{array}$ & Sesuai harapan \\
\hline 3 & $\begin{array}{l}\text { User mengklik sub kriteria } \\
\text { berat badan }\end{array}$ & $\begin{array}{l}\text { Sistem menampilkan kolom bobot untuk data sub } \\
\text { kriteria berat badan meliputi K1Sk1, K1Sk2,K1Sk3 }\end{array}$ & Sesuai harapan \\
\hline 4 & $\begin{array}{l}\text { User mengklik sub kriteria } \\
\text { tinggi badan }\end{array}$ & $\begin{array}{l}\text { Sistem menampilkan kolom bobot untuk data sub } \\
\text { kriteria tinggi badan meliputi K2Sk1, K2Sk2, K2Sk3 }\end{array}$ & Sesuai harapan \\
\hline 5 & $\begin{array}{l}\text { User mengklik sub kriteria } \\
\text { intensitas latihan }\end{array}$ & $\begin{array}{l}\text { Sistem menampilkan kolom bobot untuk data sub } \\
\text { kriteria intensitas latihan meliputi K3Sk1, }\end{array}$ & Sesuai harapan \\
K3Sk2,K3Sk3 & $\begin{array}{l}\text { Sistem menampilkan halaman hasil alternatif } \\
\text { rekomendasi latihan }\end{array}$ & Sesuai harapan \\
\hline 6 & $\begin{array}{l}\text { User mengklik button } \\
\text { simpan }\end{array}$ & & & \\
\hline & & & & \\
\hline
\end{tabular}

\section{Kesimpulan dan Saran}

Adapun kesimpulan yang dapat diambil dari sistem pendukung keputusan penentuan jenis workout menggunakan metode fuzzy analythical hierarchy process (F-AHP) pada STIKI GYM dimana sistem mampu memberikan hasil perhitungan sesuai Batasan alternatif yang diberikan dan menghsilkan rekomendasi latihan workout untuk pemula. Akurasi data hasil perhitungan sesuai dengan yang diharapkan, melalui berbagai data yang didapatkan dari STIKI GYM. Saran dalam penelitian ini yaitu khususnya dalam pengembang sistem pada bidang yang sama adalah dapat mengembangkan sistem ini lebih baik lagi kedepannya dengan memberikan pembaruan sistem yang dapat berguna dengan baik, seiring perkembangan kegunaan serta waktu pada STIKI GYM.

\section{Daftar Pustaka}

[1] W. Setiyaningsih and A. Y. E. Prasetyo, "Penerapan Fuzzy Ahp Untuk Peningkatan Ketepatan Dan Efektivitas Penilain Kinerja Karyawan," Kurawal J. Teknol. Informasi, dan Ind. ,urnal Teknol. Informasi, dan Ind., vol. 1, no. 1, pp. 21-33, 2018.

[2] E. Ekastini, K. Kusrini, and E. T. Luthfi, "Penerapan Metode Fuzzy Analytical Hierarchy Process untuk SPK Penyeleksian Naskah Layak Terbit," Creat. Inf. Technol. J., vol. 4, no. 2, p. 117 , 2018, doi: $10.24076 /$ citec.2017v4i2.103.

[3] A. Santoso, R. Rahmawati, and S. Sudarno, "APLIKASI FUZZY ANALYTICAL HIERARCHY PROCESS UNTUK MENENTUKAN PRIORITAS PELANGGAN BERKUNJUNG KE GALERI (Studi Kasus di Secondhand Semarang)," None, vol. 5, no. 2, pp. 239-248, 2016.

[4] M. A. Riyanto and M. Ugiarto, "Sistem Pendukung Keputusan Pola Olahraga Berdasarkan Hasil Yang Ingin Dicapai Menggunakan Fuzzy Database Model Tahani," vol. 2, no. 1, pp. 365-373, 2017.

[5] H. Erwanto and S. Monalisa, "Rancang Bangun Sistem Informasi Fitness Berbasis Web dan SMS Gateway pada Rajawali Fitness Pekanbaru," J. sains,Teknologi dan Ind. sains,Teknologi dan Ind., vol. 14, no. 1, pp. 72-78, 2016.

[6] A. Widarma and H. Kumala, "Sistem Pendukung Keputusan Dalam Menentukan Pengguna Listrik Subsidi Dan Nonsubsidi Menggunakan Metode Fuzzy Mamdani (Studi 
Kasus: PT. PLN Tanjung Balai)," J. Teknol. Inf., vol. 2, no. 2, p. 165, 2019, doi: 10.36294/jurti.v2i2.432.

[7] A. E. Munthafa, H. Mubarok, J. Teknik, and I. Universitas, "PENERAPAN METODE ANALYTICAL HIERARCHY PROCESS DALAM SISTEM PENDUKUNG KEPUTUSAN PENENTUAN MAHASISWA BERPRESTASI," J. Siliwangi, vol. 3, no. 2, pp. 192-201, 2017.

[8] Jasril, E. Haerani, and L. Afrianty, "Sistem Pendukung Keputusan (Spk) Pemilihan Karyawan Terbaik Menggunakan Metode Fuzzy Ahp (F- Ahp)," Chang. D. Y., (1996). Appl. Extent Anal. Method Fuzzy AHP. Eur. J. Oper. Res. 95, 649-655, vol. 2011, no. Snati 2011, pp. 17-18, 2011.

[9] F. P. Saputra, N. Hidayat, and M. T. Furqon, "Penerapan Metode Fuzzy Analytical Hierarchy Process ( F-AHP ) Untuk Menentukan Besar Pinjaman Pada Koperasi," J. Pengemb. Teknol. Inf. dan Ilmu Komput., vol. 2, no. 4, pp. 1761-1767, 2018, [Online]. Available: file:///C:/Users/DELL/Downloads/1352-1-10168-1-10-20170905.pdf.

[10] P. R. E. Pande, I. N. T. A. Putra, and N. W. S. Putri, "Rancang Bangun Sistem Informasi Pengajuan Kredit Pada Bumdesa Bersama Santhi Sedana," Telematika, vol. 17, no. 2, p. 171, 2020, doi: 10.31315/telematika.v17i2.3620.

[11] I. Zulfa, I. N. Tri, and A. Putra, "Sistem Pengambilan Keputusan untuk Penerimaan Pegawai Baru PT . PLN ( Persero ) Wilayah Aceh dengan Metode Heuristik,” vol. XI, no. 2, pp. 109-120, 1979.

[12] A. A. Widodo, S. H. Pramono, H. S. Dachlan, G. Technologi, and A. Intelligent, "Implementasi Fuzzy Analytical Hierarchy Process Menggunakan Database Maria DB," vol. 13, no. 2, pp. 84-90, 2019.

[13] I. N. Tri, A. Putra, I. K. A. Bisenna, and K. S. Kartini, "PENGEMBANGAN SISTEM INVENTARIS BERBASIS QR CODE MENGGUNAKAN WEB SERVICE PADA BIDANG SARANA DAN PRASARANA STMIK STIKOM INDONESIA,” vol. 7, pp. 315-323, 2018.

[14] I. D. M. Adi Baskara Joni and A. A. G. Bagus Ariana, "Sistem Pendukung Keputusan Seleksi Penerimaan Dosen Tetap Yayasan Dengan Metode Fuzzy -AHP," J. Ilm. Nero, vol. 1, no. 3, pp. 1-9, 2014.

[15] W. Setiyaningsih and A. Y. E. Prasetyo, "Penerapan Fuzzy Ahp Untuk Peningkatan Ketepatan Dan Efektivitas Penilain Kinerja Karyawan," Kurawal J. Teknol. Informasi, dan Ind. ,urnal Teknol. Informasi, dan Ind., vol. 1, no. 1, pp. 21-33, 2018.

[16] M. Elveny and Rahmadsyah, "Analisis Metode Fuzzy Analytic Hierarchy Process ( Fahp ) Dalam Menentukan Posisi Jabatan,” TECHSI - J. Penelit. Tek. Inform., vol. 4, 2017.

[17] S. P. Keputusan and F. Mamdani, "Sistem Pendukung Keputusan Penentuan Atlet Berbakat Menggunakan Metode Fuzzy Mamdani," Bimipa, vol. 25, no. 3, pp. 233-241, 2019.

[18] E. Ekastini, K. Kusrini, and E. T. Luthfi, "Penerapan Metode Fuzzy Analytical Hierarchy Process untuk SPK Penyeleksian Naskah Layak Terbit," Creat. Inf. Technol. J., vol. 4, no. 2, p. 117 , 2018, doi: $10.24076 /$ citec.2017v4i2.103. 
[19] A. A. Widodo, S. H. Pramono, H. S. Dachlan, G. Technologi, and A. Intelligent, "Implementasi Fuzzy Analytical Hierarchy Process Menggunakan Database Maria DB," vol. 13, no. 2, pp. 84-90, 2019.

[20] Y. Pramusinto, D. Nugroho, and Kustanto, "Sepak Bola Menggunakan Metode Analytic Hierrarchy Process ( Ahp )," TIKomSiN, no. 2338-4018, 2013.

[21] A. E. Munthafa, H. Mubarok, J. Teknik, and I. Universitas, "PENERAPAN METODE ANALYTICAL HIERARCHY PROCESS DALAM SISTEM PENDUKUNG KEPUTUSAN PENENTUAN MAHASISWA BERPRESTASI," J. Siliwangi, vol. 3, no. 2, pp. 192-201, 2017.

[22] N. R. Isyaca Fahmi, A. C. Prihandoko, and W. E. Yulia Retnani, "Implementasi Metode Fuzzy AHP pada Sistem Penunjang Keputusan Penentuan Topik Skripsi (Studi Kasus : Program Studi Sistem Informasi Universitas Jember)," Berk. Sainstek, vol. 5, no. 2, p. 76, 2017, doi: 10.19184/bst.v5i2.5533.

[23] E. J. G. Harianja and G. Lumbantoruan, "Penerapan Metode Fuzzy Analytic Hierarchy Process Dengan Metode Perceptron Pada Penentuan Klasifikasi Evaluasi Penerimaan Mobil," Comput. Eng. Sci. Syst. J., vol. 4, no. 1, p. 1, 2019, doi: 10.24114/cess.v4i1.11666.

[24] PENCAK SILAT MENGGUNAKAN METODE FUZZY AHP-TOPSIS, 01 ed. Universitas Inslam Negeri Maulana Malik Ibrahim Malang: Wahyu Joko Samudro, 2018.

[25] A. Sabiq, "Metode Fuzzy AHP dan Fuzzy TOPSIS untuk Pemilihan Distro Linux," Orbith, vol. 9, no. 2, pp. 78-83, 2013.

[26] V. A. Permadi, R. P. Agusdin, and S. P. Tahalea, "Identification of Student Area of Interest using Fuzzy Multi- Attribute Decision Making ( FMADM ) and Simple Additive Weighting ( SAW ) Methods ( Case Study: Information System Major , Universitas Pembangunan Nasional " Veteran " Yogyakarta )," vol. 1, no. 1, pp. 420-428, 2020. 